\title{
Social Organization and Agricultural Strategies to Face Climate Variability: A Case Study in Guaraciaba, Southern Brazil
}

\author{
Michelle Bonatti ${ }^{1}$, Sandro L. Schlindwein ${ }^{1}$, Ana Carolina F. de Vasconcelos ${ }^{1}$, Stefan Sieber ${ }^{2}$, Luiz Renato \\ D'Agostini $^{1}$, Marcos A. Lana ${ }^{1}$, Alfredo C. Fantini ${ }^{1}$, Larissa H. I. Homem ${ }^{1} \&$ Adriano Canci ${ }^{3}$ \\ ${ }^{1}$ Federal University of Santa Catarina, Research Group on Environmental Monitoring and Appraisal, \\ Florianopolis, Brazil \\ ${ }^{2}$ The Leibniz Centre for Agricultural Landscape Research, Institute of Socio-Economics, Muncheberg, Germany \\ ${ }^{3}$ The Central Association of River Basins, Guaraciaba, Brazil \\ Correspondence: Michelle Bonatti, Federal University of Santa Catarina, Research Group on Environmental \\ Monitoring and Appraisal. Rodovia Admar Gonzaga, 1346. Cx.P. 476, Itacorubi, CEP: 88040900. Florianópolis, \\ SC Brazil. E-mail: michebonatti@gmail.com
}

Received: September 20, 2012 Accepted: May 25, 2013 Online Published: May 30, 2013

doi:10.5539/sar.v2n3p118 URL: http://dx.doi.org/10.5539/sar.v2n3p118

This research was supported by the European Community's Seventh Framework Programme (FP7/2007-2013) under Grant Agreement no. 212492: CLARIS LPB

\begin{abstract}
Climate scenarios and projections have suggested that the impacts of climate change on land use will be noticed particularly by the communities that depend on natural resources for their subsistence. The climate vulnerability of poor communities varies greatly, but in general, climate change combines with other threats and becomes superimposed on existing vulnerabilities. This paper presents a case study that strives to understand the social organization in a vulnerable community of Guaraciaba, in southern Brazil, to investigate aspects of an adaptation strategy to climate change based on the local development and conservation of landraces of a set of crop species. Landraces are varieties better adapted to adversities, especially drought, which is an important threat to the famers in the region. Every farmer receives annually a "kit of biodiversity", a set of local varieties with the amount of seeds necessary to be cultivated in order to produce enough food for the family. The study had a qualitative approach and was carried out through semi-structured interviews with technicians and 30\% of the rural families who farm with landraces. The study concludes that the factors that make this adaptation strategy sustainable are: the ability to undertake actions strongly based on local socio-cultural needs (a social support network), biodiversity management practices designed to reduce external economic dependence, self management of genetic resources, the establishment of priorities based on locally available resources, a work plan for community participation (field days, a community based festival), the establishment of the roles of community in the planning and implementation of programs for biodiversity management.
\end{abstract}

Keywords: adaptation strategies, climate change, agriculture, smallholders

\section{Introduction}

According to different climate scenarios and projections, changes in climatic zones are in progress and are likely to increase the frequency and intensity of droughts, heavy rains, and other extreme weather events (Assad \& Pinto, 2008; International Panel to Climate Change [IPCC], 2007). In Brazil, for example, heavy rains and droughts have gone from exceptional events to frequent episodes in many communities. Concerning the risks of climate change and variability to humanity, the report "Climate Change - The Anatomy of a Silent Crisis" indicates that extreme weather caused by climate change each year leaves over 300,000 people dead, 325 million people seriously affected, and economic losses of US $\$ 125$ billion. Four billion people are vulnerable, and 500 million people are at extreme risk (Global Humanitarian Forum, 2009).

Poor communities are particularly affected because climate change combines with other threats to expose factors that compound vulnerability. Climate change will reduce access to drinking water, negatively affecting the health of poor people, and create a real threat to food security in many countries, especially in Africa, Asia, and Latin 
America. Natural resource constraints and limited availability of productive land and water in some regions pose substantial challenges to producing food at affordable prices. In some areas where livelihood choices are limited, lower crop yields will cause food scarcity (Food and Agriculture Organization of United Nations [FAO], 2011).

Since climate change and variability may generate strong impacts on agricultural land use, agriculture is increasingly becoming unviable for smallholders and their production systems will deteriorate progressively. Among the factors responsible for this situation include the increasing expansion of the private sector over the land of smallholders, poor access to markets, illiteracy, environmental issues and lack of political will. Therefore, smallholders may enter a vicious cycle of rising debt, increasing input costs and weakening financial returns (FAO, 2012).

To face rapidly changing farming and environmental conditions caused by climate change, farmers need to be able to plan and quickly respond to such changes, generating flexible innovative systems. Considering this complex problematic situation, the initiative of small farmers in Guaraciaba, a municipality of Santa Catarina State, in southern Brazil, is remarkable. A number of climate adaptation strategies have been developed and adopted by a group of smallholders in the location, such as the use of landraces more adapted to drought (Bonatti, 2009).

However, more than the technical adoption of an adaptation strategy by smallholders, it is important to investigate how rural communities are organized in order to assess and evaluate the effectiveness of the adaptation strategies developed and adopted. In this context, this paper presents a study that investigates some aspects of social organization in Guaraciaba.

\subsection{Climate Conditions, Social Organization and Adaptive Capacity}

Adaptation can be considered a natural process: given that animals are alive, their continuous process of adaptation in order to survive can be observed. However, adaptation can be either a spontaneous or a conscious (intentional) process. In general terms, adapting to a specific situation means to fit in, become accustomed, or change to reach a goal. It also involves adjusting to new conditions imposed by the environment. The concept of adaptation has been explored by researchers from different disciplines and it has different meanings and interpretations in biology, medicine, psychology, sociology, geography and many others disciplines.

From a social perspective, Laraia (2005) presents the idea of culture as an adaptive system: cultures are systems of behavior patterns that are socially transmitted to adapt human communities according to their biological bases. Therefore, cultural and social aspects may be determinants of both the state of vulnerability and of the climate adaptation process in a community. From this point of view, the concepts of adaptation and culture share a common interface because they both might be considered human procedures of evolution adapted to survive climate adversities. Human beings have always developed adaptive systems according to their cultural and living conditions to survive in a particular geographical zone. Changes in climate have promoted and motivated cultural transformations in different periods of evolutionary history and evidence of these changes are especially noticeable in agriculture and architecture, since these human activity systems are strongly conditioned by climatic factors (Fagan, 2009).

According to Adger (2003), decisions about adaptation are made by different agents, including individuals, groups, organizations, and governments on behalf of the whole society. However, these decisions very often privilege some sets of interests over others, creating winners and losers. Thus, the effectiveness of any adaptation strategy to climate change will depend on its social acceptability, on the existing political institutions, and on the economic and social-cultural development of the society in question. In this sense, it is important to study the social organization of a community and its modus operandi as inseparable aspects of human agency.

For Nagy et al. (2006) climate adaptation is the process through which stakeholders reduce the adverse effects of climate on their livelihood. This process involves passive, reactive, or anticipatory behavior adjustments and economic structures that can increase sustainability and reduce vulnerability to extreme climate events. An adaptation strategy is effective when it reduces the impact of a potential threat and increases the adaptation capacity (Nagy et al., 2006; Burton \& Lim, 2005). For example, in recent decades a very strong rural exodus from the rural municipalities of Santa Catarina State has been observed, which might be considered a survival strategy for most family farmers. Processes like migration are strategies used by different species and are also cultural processes that different population groups use in an attempt to better adapt and find better living conditions than those they left (Fagan, 2009).

Finally, to face adverse climate conditions, vulnerability and adaptation must be considered as a duality in order to understand the existing possibilities available to decrease the impacts of climate change on society. Climate change adaptation can also be understood as an opportunity to rethink the state of vulnerability of a given system 
of interest, especially in developing countries, and to reflect about the conditions and relationships that sustain development in these countries. In this sense, it is possible to use climatic events as opportunities to transform development conditions, understanding adaptation as an intentional, conscious process that can improve society.

In order to foster new kinds of adaptation, it is important to understand how local social organization can empower the adaptation process. The distinct cultural aspects of social organization include knowing the roles played by individuals in society and the strategies and relations that arise from their performances. To understand this social dynamic means understanding who are the social actors, what are their roles in relation to the system of interest (neighborhood or community) and what is the network of working relationships, among other aspects. Individually, each person develops a personality and behavior in a form that is intrinsically linked to the cultural context, in order to adapt to the world. These aspects have also been investigated in this case study.

\section{Area Description}

\subsection{Guaraciaba: Site Features and Vulnerability}

The municipality of Guaraciaba is located at $26^{\circ} 30^{\prime}$ South latitude and $50^{\circ} 30^{\prime}$ West longitude, in the Western region of Santa Catarina State, Brazil, 730 kilometers from the state capital, Florianópolis, and 65 kilometers from the province of Misiones in Argentina (Figure 1). Guaraciaba has $331.1 \mathrm{~km}^{2}$ and an estimated population of 11,000 inhabitants, $60.5 \%$ of whom live in rural areas. The rural population comprises about 1,500 farm families who mainly raise cattle and swine, and cultivate maize and tobacco among other subsistence crops, on farms with an average area of 18.0 ha. The climate is classified as Cfa (subtropical climate): temperate, humid, mesothermal with a warm rainy summer. The average annual temperature is $18^{\circ} \mathrm{C}$, and at the extremes there are frosts and temperatures up to $33{ }^{\circ} \mathrm{C}$ (Canci, 2004). Guaraciaba is an example of a municipality located within the La Plata River Basin in which smallholders have suffered the consequences of extreme weather events such as droughts, frosts and a tornado, which have caused losses in agricultural production and human deaths. Therefore, local agriculture could be heavily impacted if there is an increased frequency of extreme weather events generated by climate change.

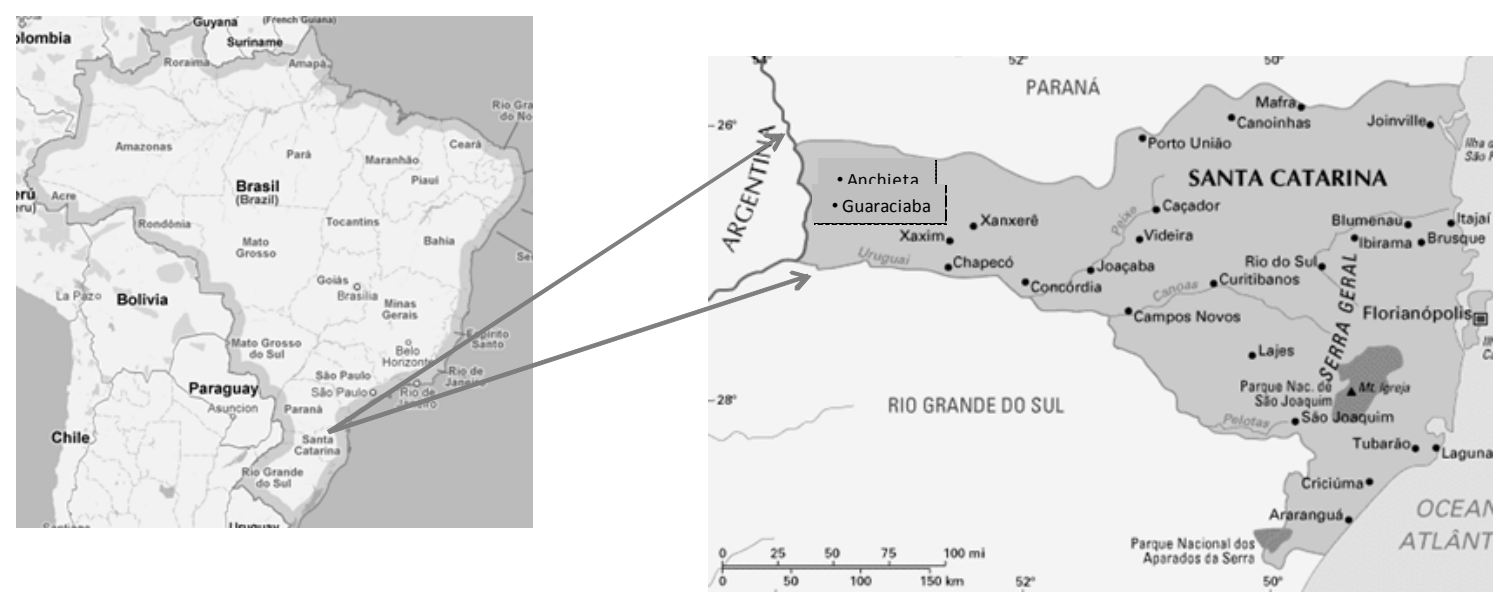

Figure 1. Location of Guaraciaba within Santa Catarina State, Brazil

Source: Adapted from Zuchiwschi (2008) and Google Maps

(http://maps.google.com.br/maps?hl=pt-BR\&tab=wl)

According to Cardona (2001) the risk of disasters in a given system of interest depends on two factors: on the magnitude of the threat and on the state of vulnerability of this system. Consequently, a decrease in one of these factors leads to a reduction of risk as a whole. Considering a given system of interest, such as an agricultural system or a community, the threat corresponds to an external risk factor, and although it can often be predicted, it usually cannot be fully controlled. Vulnerability, however, corresponds to an internal risk factor, determined by social conditions, and is therefore constructed through human actions.

The social and environmental factors found in Guaraciaba reveal the municipality's vulnerability to climate change: the small size of farms (up to 30 hectares), the dependence on family labor and subsistence agriculture, the low level of mechanization in agricultural activities and the limited financial resources. These features make the agricultural systems highly vulnerable to extreme climatic events. The local vulnerability, therefore, is related 
to biophysical aspects such as the terrain and adverse environmental conditions, but also to socio-cultural aspects such as low income and heavy reliance on subsistence from local production.

\subsection{Landraces Cultivation as an Adaptation Process}

Canci (2004) observed that some farmers in Guaraciaba have cultivated and preserved for their own consumption 34 main species of landraces, such as corn and beans, which have a great genetic biodiversity, including more than 200 local varieties (clones). These varieties were preserved because they have a special taste, or because their cultivation was a family tradition, and have helped to reduce the maintenance costs on the farms. To combine all these factors, a "biodiversity kit" was created by selecting local varieties of crops that are better adapted to the farming conditions of the region in a participative process that included farmers, agricultural technicians, scientists, students and other community members. This "kit" has been considered a clear initiative to adapt the local agricultural systems to extreme climate events. It is also an example that allows investigating how climate variability can create a stimulant to transform the local state of vulnerability.

The process that led to the development of the "biodiversity kit" was initiated by technicians who conducted a participatory rapid appraisal to preserve the popular knowledge of farmers about the names of crop varieties, their origin and seed conservation measures, their crop management practices, resistance to disease and pests, harvest and storage methods, and their resistance to adverse climate conditions. The characteristics for the use, preparation and consumption of these crops were studied based on records made by the families over time. The varieties that presented better adaptation to local climate and other geographic conditions were selected to integrate the "kit" (Guadagnin, 2006).

These local varieties developed by smallholders over many years have been highlighted as special and valuable crop resources with many desirable qualities, such as resilience (Ogliari, Alves; Kist; Fonseca; Balbinot, 2007). Genetically, these varieties can be defined as geographically or ecologically distinct cultivated populations that have a diverse genetic composition and are adapted to local agro-climatic conditions. The unique adaptation of these varieties to the local environmental conditions makes the local farming systems more sustainable, with fewer demands on inputs helping to conserve the local natural resources.

\section{Methods}

Considering the subjective and psychosocial character of the research issues, a qualitative approach was adopted for this case study. According to Neiman and Quaranta (2007), "a case study can be conducted of a fact, a group, a relationship, an institution, an organization, a social process or a specific situation or scenario, built from a certain slice of social reality, which is always subjective and partial, empirical and conceptual, forming an issue for a study or a problem".

The field research involved semi-structured interviews with local farmers, which were transcribed to a field diary. According to Queiroz (1988), the interview is a technique for data collection that involves a conversation between the informant and the researcher, and is organized according to the research goals. According to Sautu (2005), this technique is characterized as "a systematic conversation that aims to obtain, retrieve and record everyday life experiences of people or their concepts". During the interviews, the researcher must present the questions in the local language, allowing the informants to talk about their histories and situations, without interruption or judgment.

The interview stage of this study was also useful for investigating the local expressions and the existing social relationships that compose the local social organization. Considering the communicative context, it is important to note how the interviewer is received by the respondent, the willingness to answer questions, the interview location, how the respondent is positioned, and other factors that can influence the interviewee's acceptance of the researcher (Duarte, 2002). The interviews for this study were audio taped with the permission of the respondents, without identifying their names. The interviews were divided into three parts: a) presentation of the purpose of the study and the interviewers b) general questions about the local climate and agricultural production, and finally c) life history, important events and social support network. The interviews lasted an average of 45 minutes.

Two parameters were considered to establish the number of respondents: a) families in the community that cultivate landraces (about $30 \%$ of the total number of farm families in the community cultivate landraces), to understand their universe in this innovative experience, and b) the number of answers necessary to identify common lines of thinking among the respondents, such as a universe of meaning, symbolic systems, codes, values, attitudes and ideas. Thus, the field investigation was interrupted when it was verified that the material obtained from the interviews could identify logical and symbolic patterns and practices. In total, fifteen families 
were interviewed. The analysis of the data obtained was based on the responses of the family members in each interview. The interviewees ranged in age from 30 to 70 with an average age of 45 . In addition, all the farmers interviewed owned their properties.

An important factor in the analysis of the results is the researcher's ability to perceive in the speeches of the respondents nuances of language and consider the context of the communication. The researcher is responsible for reviewing the discourses and the circumstances in which they occur. Therefore, the procedures adopted to analyze and interpret the results were:

a) To transcribe the responses of all the respondents with the identification of key words perceived during the interview;

b) To diagnose the occurrence of contradictions, the recurrence of statements, the use of rhetoric and any other subtle details (silence, doubt and hesitation) in each interview;

c) To associate the information obtained in the interviews with the social context of Guaraciaba.

\section{Results}

The results will be described considering two main aspects: the "agricultural activities, land use and biodiversity" present in the farms visited, and the "social structure and social support network" of the communities studied.

\subsection{Agricultural Activities, Land Use and Biodiversity}

The farmers interviewed in this study own their rural properties, which range from 8 to 45 hectares. Although the farmers own their land, they do not have the resources and technologies needed for processing their agricultural products and to certify them as organic as required by the market for "bio products". Therefore, in Guaraciaba, there is no difference in the marketing between landrace products (from organic farming) and conventional products, and the organic products are sold in an informal market or directly to consumers. Furthermore, there are no public policies to promote products from small farmers in the local or nearby international markets, creating the need for developing policies that consider the major differences between farmers with strong purchasing power from those with less purchasing power. In this situation, it is necessary to assure the appropriate technical support and political will needed to foster the production of landraces with a lower use of fertilizers and other farm inputs, thus reducing production costs. The seeds used by these farmers come from their own cultivation and have been preserved as the result of an inter-generational family process and/or an exchange with neighbors, as described by Guadagnin, Guadagnin, Canci and Porerekan (2007). This autonomy in the production and availability of seeds assures a certain level of food security and therefore characterizes a social reproduction and identity strategy of this rural community.

One of the main outcomes of this study is the finding that agricultural production is mainly for the self consumption of the interviewed families. These families produce basically all that they consume (vegetal and animal products), strengthening the existence of a subsistence agriculture, in which livelihood is strongly dependent on land use.

The farmers interviewed highlighted important environmental aspects involved in cultivating landraces, such as their ability to adapt to local climate conditions, lower need for inputs such as fertilizers, lower levels of attack by pests and diseases, their resistance to droughts, and good yields in intercropping systems. As a result, farmers do not need high amounts of financial resources to invest in seeds and other agricultural inputs, and the production cost is relatively low. Farmers also say that while the income from cultivating landraces is lower than that for the cultivation of hybrid varieties, the yields of the landraces are more stable over the years.

\subsection{The Social Organization and the Social Support Network}

The organization of rural households differs essentially from urban households because in rural households the family unit coincides with the production unit: parents, children, and sometimes grandparents work together on their properties since they are all responsible for agricultural production and survival. But the rural exodus of young people is increasingly resulting in a smaller workforce, causing significant changes in the forms of production on the properties, such as shifts from planted crops to milk production.

The families interviewed were also asked to whom do they turn to for help in case of adverse situations and most indicated their neighbors. This is because there is only a small difference between family and neighbor relationships in the communities studied, and in case of an emergency, the farmers find their main social support network among neighbors, since the number of relatives residing in the same community is usually low. 
Another important aspect of the existing social structure that supports the process of climate adaptation in Guaraciaba was observed in this case study: the collaboration between farmers and technicians, which together with the social support network, helps create the circumstances for the maintenance of family farming. This collaborative work has been recognized by farmers as essential for fostering the exchange of seeds among the communities, and is acknowledged as an important channel for exchanging local knowledge. Therefore, the community network can be considered as an important social technology in the process of adapting to situations of risk or providing assistance in emergency situations caused by natural disasters.

Finally, the farmers mentioned that since 2005, when the program for the conservation and exchange of landraces was initiated to improve food security in agricultural communities of Guaraciaba, the number of participating families gradually increased. Based on the social network existing in the communities, the activities of some farmers and technicians were identified as essential in the persistent exchange and distribution of landrace seeds, by organizing a work plan for community engagement (with field days and community based festivities).

\section{Discussion}

In Guaraciaba, the existence of a cohesive social support network is an important factor that helps reduce the vulnerability of the local agricultural systems and facilitate the adoption of adaptation strategies to minimize the impacts of adverse events such as those likely to be caused by climate change. Social networks are constituted by a set of interpersonal ties that extend beyond the life of an individual, and that include "family, friends, relationships, work, study, inclusion in the community and social practices" (More, 2005, p 37). These links can also include institutions and technicians in the region that are mentioned as references in times of crisis, as well as counseling and public services (hospital, public safety, local government, church). According to More (2005), social networks appear as important objects of analysis in the theory of Lewin, which include variables that focus on informal relationships and in Moreno (1951), the creator of psychodrama, who developed the sociogram technique to outline a relationship network.

In this sense, fostering social networks and stakeholding should be more frequently considered to be the goal when designing and implementing public policies. It is important to generate measures that promote and strengthen existing social support networks. The strengthening might be developed through relationships with institutions and technicians, and also by encouraging the cohesion of the community to help achieve goals of survival, territorial development and adaptation strategies against extreme weather events.

The smallholders mentioned that the joint efforts of some technicians and farmers were important initiatives for the long-term production of landraces. This might be considered as the result of the action of "nodal farmers". Nodal farmers are able to generate and distribute landraces to farmers located in other agricultural communities and are important sources of local knowledge about landraces (Pinedo et al., 2009).

\section{Conclusions}

The main factors that make the situation in Guaraciaba a case study about the development of a sustainable adaptation strategy are: the local ability to undertake actions strongly based on the local social support network, the use of biodiversity management practices that reduce external economic dependence, the self-management of genetic resources, the establishment of priorities based on locally available resources, the existence of work plans for community engagement, the establishment of partnerships with other institutions, and the consolidation of the roles of community members in the planning and implementation of the biodiversity management program.

In this context, and considering that a given population can develop its own strategies for developing a sustainable livelihood and maintain its ongoing process of adaptive evolution, the use of landraces in Guaraciaba might be considered a remarkable adaptation strategy by agricultural producers to face climate adversities. Surely, this specific strategy is integrated to a large adaptive cultural system, allowing the community to make its agricultural production more efficient and lower costs, even for that production dedicated to self-consumption. Therefore, this local initiative found in Guaraciaba presents an opportunity for territorial development especially if more consistent support from public policies was provided.

In Guaraciaba, small-scale and subsistence agriculture is also strongly associated with local and traditional knowledge, the organization of farmers to manage natural resources and the improvement of participatory processes. It is important to consider that the actions of farmers based on the knowledge they have about their reality is a key element in their ability to adapt to climate change. Knowledge and collective actions can be the core of economic growth and development, and the understanding of how people and societies acquire and use them- and why they sometimes fail to do so - is essential in improving the quality of people's lives. 
It can also be concluded that the process of designing adaptation strategies to climate change should consider not only technical issues but also all aspects that are perceived as important for the development of the community. In this sense, an important economic aspect of the strategy developed in Guaraciaba is that the landrace seeds are much less expensive than those of hybrid crop varieties, and in many cases they are obtained free-of-charge in an exchange system among the farmers. Another important factor in the domestic economy of these rural families is that the major portion of their agricultural production is for their own consumption.

Adaptation to climate change for people living in poverty conditions involves surviving all possible threats that are confronted in everyday life. In this sense, any adaptation strategy to climate change and variability must be multidimensional and able to meet different social community needs. Therefore, to develop public polices for adaptation purposes it is fundamental to look at the vulnerability of the community as a whole, to be able to design an integrated adaptation strategy.

Finally, concerning social organization, despite the important role played by landraces in the resilience of local agricultural systems, Guaraciaba is still characterized by youth migration to urban centers. This situation is associated to a complex network of relationships involving not only current land use or the possible threats of climate change and variability, but also to the inexistence of public policies that could improve quality of life in rural areas.

\section{Acknowledgements}

The authors would like to thank all the families interviewed who agreed to collaborate with this case study in Guaraciaba. The research leading to these results received funding from the European Community's Seventh Framework Programme (FP7/2007-2013) under Grant Agreement no. 212492: CLARIS LPB - A Europe-South America Network for Climate Change Assessment and Impact Studies in La Plata Basin.

\section{References}

Adger, W. N. (2003). Social Capital, Collective Action, and Adaptation to Climate Change. Economic Geography, 79(4), 387-404. http://dx.doi.org/10.1111/j.1944-8287.2003.tb00220.x

Adger, W. N. (2006). Vulnerability. Global Environmental Change, 16, 268-281. http://dx.doi.org.ezproxy.lib.vt.edu:8080/10.1016/j.gloenvcha.2006.02.006

Assad, E. D., \& Pinto, H. S. (Coord.). (2008). Aquecimento global e cenários futuros da agricultura brasileira (p. 84). São Paulo: EMBRAPA/UNICAMP.

Boisier, S. (2003). ¿Y si el desarrollo fuese una emergencia sistémica? Revista del CLAD Reforma y Democracia, 27.

Bonatti, M. Cambios climáticos. Percepciones humanas y desarrollo rural. (2011). Dissertação (Mestrado). Universidade de Buenos Aires. Programa de Pós-Graduação em Desenvolvimento Rural. Buenos Aires.

Burton, I., \& Lim, B. (2005). Achieving adequate adaptation in agriculture. Climatic Change, 70, 191-200. http://dx.doi.org.ezproxy.lib.vt.edu:10.1007/s10584-005-5942-z.

Canci, I. J. (2004). A diversidade das espécies crioulas em Anchieta-SC: Diagnóstico resultado de pesquisa e outros apontamentos da agrobiodiversidade (p. 112). São Miguel do Oeste: Mclee.

Cardona, O. (2001). La necesidad de repensar de manera holística los conceptos de vulnerabilidad y riesgo. Una crítica y una revisión necesaria para la gestión. Red de Estudios Sociales en Prevención de Desastres en América Latina. Universidad de Los Andes. Bogotá. p. 18. Retrieved Feburary 24, 2012, from http://www.desenredando.org/public/articulos/2001/repvuln/index.html

Duarte, R. (2007). Pesquisa qualitativa: reflexões sobre o trabalho de campo. Cadernos de Pesquisa. Departamento de Educação da Pontifícia Universidade Católica do Rio de Janeiro, 115.

Fagan, B. (2009). O aquecimento global: a influência do clima no apogeu e declínio das civilizações (p. 303). São Paulo: Larousse do Brasil.

Food and Agriculture Organization of the United Nations. FAO. (2012). Report of the FAO Expert Consultation on Agricultural Innovation Systems and Family Farming (p. 27). FAO: Rome.

Food and Agriculture Organization of the United Nations. The State of Food Insecurity in the World. FAO. (2011). Rome, p. 55. 
Guadagnin, C. A., Guadagnin, C. M. I., Canci, A., \& Porerekan, C. D. (2006). Kit diversidade: uma alternativa sustentável na produção de alimentos para Autoconsumo. Revista Brasileira de Agroecologia, 2(2), 295-298.

Human Impact Report: Climate Change - The Anatomy of a Silent Crisis. Global Humanitarian Forum, Geneva, (2009). Retrieved March 15, 2012, from http://www.ghf-ge.org/human-impact-report.pdf

IPCC. Intergovernmental Panel on Climate Change. (2007). Summary for policy makers. In: Climate Change: The Physical Science Basis. Contribution of Working Group I to the Fourth Assessment Report of the Intergovernmental Panel on Climate Change (p. 18). Cambridge United Kingdom and New York: University Press.

Laraia, R. B. (2005). Cultura: um conceito antropológico. Rio de Janeiro: In Jorge Zahar (Ed.).

Marengo, J. A., \& Valverde, M. C. (2007). Caracterização do clima no Século XX e Cenário de Mudanças de clima para o Brasil no Século XXI usando os modelos do IPCC-AR4. Revista Multiciência, 8, 5-28.

Martins, S. R. M., Schlindwein, S. L., D’Agostini, L. R., Bonatti, M., Vasconcelos, A. C. F., Hoffmann, A. F., \& Fantini, A. C. (2010). Mudanças climáticas e vulnerabilidade na agricultura: desafios para desenvolvimento de estratégias de mitigação e adaptação. Revista Brasileira de Ciências Ambientais, 17, 17-27.

More, C. L. O. (2005). As redes pessoais significativas como instrumento de intervenção psicológica no contexto comunitário. Paidéia, 15(31), 287-297. http://dx.doi.org/10.1590/S0103-863X2005000200016

Nagy, G. J., Bidegain, R. M., Caffera, J. J., Lagomarsino, W., Norbis, A., Ponce, S., \& Sención, G. (2006). Adaptive Capacity for Responding to Climate Variability and Change in Estuarine Fisheries of the Rio de la Plata. AIACC Working Paper, 36.

Neiman, G., \& Quaranta, G. (2007). Los estudios de caso en la Investigación Sociológica. In I. Gialdino (Ed.), Estrategias de investigación cualitativa,

Ogliari, J., Alves, A. C., Kist, V., Fonseca, J. A., \& Balbinot, A. (2007). Análise da diversidade genética de variedades locais de milho. Revista Brasileira de Agroecologia, 2(1), 191-195.

Pinedo, R., Collado, L., Latournerie, L., Castiñeiras, L., Barrios, O., \& Mijangos, J. (2009). El agricultor nudo en la dinámica del sistema informal de semillas. In M. Hermann, K. Amaya, L. Latournerie \& L. Castiñeiras (Eds.), ¿Cómo conservan los agricultores sus semillas en el trópico húmedo de Cuba, México y Perú? Experiencias de un proyecto de investigación en sistemas informales de semillas de chile, frijoles y maíz. Bioversity International, Roma.

Queiroz, M. I. P., Relatos orais: do "indizível” ao "dizível". (1988). In O. M. Von Simson (Ed.), Experimentos com histórias de vida (Itália-Brasil). São Paulo: Vértice, Editora Revista dos Tribunais, Enciclopédia Aberta de Ciências Sociais, 5, 68-80,

Sautu, R. (2005). Manual de metodología: construcción del marco teórico, formulación de los objetivos elección de la metodología Buenos Aires (p. 192). Consejo Latinoamericano de Ciencias Sociales- CLACSO.

Zuchiwschi, E. (2008). Florestas nativas na agricultura familiar de Anchieta, Oeste de Santa Catarina: conhecimentos, usos e importância. Master degree thesis: Recursos Genéticos Vegetais - Universidade Federal de Santa Catarina, Florianópolis, Brasil.

\section{Copyrights}

Copyright for this article is retained by the author(s), with first publication rights granted to the journal.

This is an open-access article distributed under the terms and conditions of the Creative Commons Attribution license (http://creativecommons.org/licenses/by/3.0/). 